AT-TAJDID: Jurnal Pendidikan Dan Pemikiran Islam

(p-ISSN: 2548-5784 |e-ISSN: 2549-2101)

Vol. (5) (01), (Januari-Juni) (2021), (83-92)

Doi: http://dx.doi.org/10.24127/att.v5i01.1597

\title{
PENDEKATAN FENOMENOLOGIS DALAM KAJIAN ISLAM
}

\author{
Afif Syaiful Mahmudin \\ Institut Agama Islam Negeri (IAIN) Ponorogo \\ afifsyaifulmahmudin7@gmail.com
}

\begin{abstract}
ABSTRAK
Penelitian terhadap agama tidak hanya berpatokan pada konsep normatif dari agama itu sendiri ataupun hanya mengacu pada ilmu-ilmu sosial, tetapi keduanya harus saling melengkapi. Peneliti yang kurang memahami agama yang sedang dikaji, pasti akan mengalami berbagai kesulitan karena realitas agama harus dilihat dari konsep agama itu sendiri. Berangkat dari problematika di atas, berbagai pendekatan metodologis dalam kajian atau studi Agama berhasil mendapatkan perhatian yang cukup besar dari para pemerhati agama. Kemudian dalam perkembangan studi Agama telah dirumuskan berbagai pendekatan yang berasal dari berbagai disiplin ilmu seperti filsafat, antropologi, sosiologi, sejarah, psikologi sampai kepada pendekatan fenomenologi. Pendekatan yang terakhir inilah yang akan menjadi pembahasan utama dari tulisan ini, fenomenologi agama menjadi sebuah kajian yang dilaksanakan untuk mencari makna atau esensi melalui manifestasi dari fenomena-fenomena keagamaan dalam suatu agama tertentu. Pendekatan fenomenologi dalam studi Islam berupaya mengungkapkan makna dari suatu gejala sehingga gejala tersebut dapat dipahami dan dapat diterapkan dalam ajaran-ajaran normatif, kegiatan-kegiatan keagamaan, institusi-institusi keagamaan, tradisitradisi dan simbol-simbol keagamaan.
\end{abstract}

Kata Kunci: Pendekatan, fenomenologi, studi Islam

\begin{abstract}
Research on religion is not only based on the normative concept of religion itself or only refers to the social sciences, but both must complement each other. Researchers who do not understand the religion being studied will definitely experience various difficulties because the reality of religion must be seen from the concept of religion itself. Departing from the problems above, various methodological approaches in religious studies have managed to get considerable attention from religious observers. Then in the development of the study of Religion, various approaches have been formulated from various disciplines such as philosophy, anthropology, sociology, history, psychology to the phenomenological approach. This last approach will be the main discussion of this paper, the phenomenology of religion is a study carried out to find meaning or essence through the manifestation of religious phenomena in a particular religion. The phenomenological approach in Islamic studies seeks to reveal the meaning of a phenomenon so that the phenomenon can be understood and can be applied in normative teachings, religious activities, religious institutions, traditions and religious symbols.
\end{abstract}

Keywords: approach, phenomenology, Islamic studies 


\section{A. PENDAHULUAN}

Agama merupakan sebuah ekspresi simbolik dan juga sebagai respon seseorang terhadap sesuatu yang dipahaminya dan dianggap memiliki nilai yang tidak terbatas. Ekspresi simbolik inilah yang menjadi karakter utama seseorang dalam mencari makna agama. Oleh karena itu, tema-tema pokok penelitian tentang agama selalu berkaitan dengan fakta agama serta pengungkapannya. Pengertian ini dalam bahasa sederhana dipahami dengan usaha menjadikan agama sebagai objek dari penelitian. Data-data yang diambil dalam penelitian agama berasal dari hasil pengamatan terhadap kebiasaan, serta tingkah laku manusia dalam mengekspresikan agama melalui kegiatan nyata seperti melakukan ritual, berdoa, keyakinan pada hal-hal ghaib dan hal lain yang mencerminkan sejauh mana pemahaman seseorang terhadap agama.Meski dalam konteks yang sama, pengamatan terhadap agamaditinjau dari berbagai disiplin ilmu akan menghasilkan sesuatu yang berbeda tergantung dari aspek dan tujuan jangkauannya. (Dhavamony, 1995).

Penelitian terhadap agama tidak hanya berpatokan pada konsep normatif dari agama itu sendiri ataupun hanya mengacu pada ilmu-ilmu sosial, tetapi keduanya harus saling melengkapi. Peneliti yang kurang memahami agama yang sedang dikaji, pasti akan mengalami berbagai kesulitan karena realitas agama harus dilihat dari konsep agama itu sendiri. (Abdullah, 2004).

Berangkat dari problematika di atas, berbagai pendekatan metodologis dalam kajian atau studi Agama berhasil mendapatkan perhatian yang cukup besar dari para pemerhati agama. Kemudian dalam perkembangan studi Agama telah dirumuskan berbagai pendekatan yang berasal dari berbagai disiplin ilmu seperti filsafat, antropologi, sosiologi, sejarah, psikologi sampai kepada pendekatan fenomenologi. Pendekatan yang terakhir inilah yang akan menjadi pembahasan utama dari tulisan ini, fenomenologi agama menjadi sebuah kajian yang dilaksanakan untuk mencari makna atau esensi melalui manifestasi dari fenomena-fenomena keagamaan dalam suatu agama tertentu.

\section{B. PEMBAHASAN}

\section{Pengertian Fenomenologi dan Pendekatannya}

Secara bahasa, kata fenomenologi diadopsi dari bahasa Yunani cari kata "phainein" yang memiliki makna memperlihatkan. Kemudian dari kata tersebut muncul "phainemeon" yang bermakna suatu yang muncul. (Khoir, 2009) Dalam bahasa sederhana fenomenologi berarti kembali pada sesuatu itu sendiri (backtothethingsthemselves). Hadiwijoyo menambahkan, bahwa kata fenomenologi bermaknna "penampakan" seperti demam, batuk, meriang yang menunjukkan fenomena gejala dari penyakit. (Hadiwijoyo, 1992).

Istilah fenomenologi pertama kali diperkenalkan oleh EdmurtHussert seorang filosof berkebangsaan Jerman yang hidup antara tahun 1859 sampai $1901 \mathrm{M}$ dalam sebuah karya yang diberi judul LogischeUnteruschungenyang memuat rancangan fenomenologi. (Khoir, 2009) Dia mengatakan dalam bukunya tersebut bahwa fenomenologi harus sangat cermat dan detail bisa menempatkan fenomenologi dengan fakta yang terjadi di dunia luar. Berawal dari sinilah, pada tahun 1970-an istilah fenomenologi mulai digunakan dalam berbagai disiplin ilmu sebagai salah satu pendekatan metodologi dan secara 
besar-besaran melakukan kegiatan penerjemahan karya-karya dari Husserli. Maka dari itu, mulai tahun 1970 sampai sekarang menjadi patokan utama dalam pendekatan fenomenologi. (Muhadjir, 1998)

Sejatinya, pendekatan fenomenologi adalah bentuk pendekatan ilmiah yang berupaya mencari esensi atau hakikat dibalik suatu kejadian dalam hal ini adalah manifestasi agama yang terjadi di dalam kehidupan manusia. (Abdullah, 1996) Tidak seperti aliran-aliran filsafat sebelumnya, fenomenologi tidak mengedepankan pandangan yang eksklusif yang justru malah menjadikan isme-isme yang beraneka ragam tetapi hanya sebagai metode dalam mendekati sebuah persoalan. Jika dilihat khusus dari agama, istilah fenomenologi sendiri mulai diperkenalkan oleh G. Van Der Leeuw dalam karyanya " PhanomenologiederReligion" yang saat ini lebih dikenal dengan istilah fenomenologi agama.

2. Studi Agama dengan Pendekatan Fenomenologis

Termasuk dalam studi agama, pendekatan fenomenologi menjadi suatu metode dalam memahami agama lain dengan sudut pandang netral serta menanggalkan identitas diri sendiri (epoche) serta berusaha menghadirkan pengalaman keagamaan dari orang lain. (Abdullah, 1996)

Orientasi kajian fenomenologi agama ialah pengalaman keagamaan dari seseorang yang dijelaskan atau digambarkan fenomena tersebut secara konsisten yang berpatokan pada keimanan atau kepercayaan dari objek penelitian. Fenomenologi melihat suatu agama menjadi sebuah komponen yang berbedabeda lalu diteliti secara hati-hati sesuai dengan tradisi maupun ritual keagamaan yang dijalankan pemeluk agama tersebut. Penekanannya adalah, fenomenologi agama timbul sebagai usaha untuk menghindarkan seseorang memakai pendekatan yang sempit, normatif dan etnosentris terhadap agama serta berusaha mengelaborasikan semua pengalaman agama seakurat mungkin.

Jika dicermati lebih jauh dari cara kerja pendekatan fenomenologi, seseorang akan merasa sulit menghindari pengaruh dari pendekatan filsafat dalam pendekatan fenomenologinya. Sebenarnya yang terjadi ialah,justru dengan pendekatan fenomenologi inilah yang berjasa dalam mendapatkan pengetahuan baru saat mencari esensi dari keberagamaan manusia. Seiring berjalannya waktu, pendekatan ini dikembangkan kembali oleh W.B Kristensen, Rudolf Otto, MirceaEliade dan juga oleh G. VanderLeeuw yang samasama bahwa fokus utama dari fenomenologi ialah pencarian makna dan struktur fundamental dari pengalaman beragama. (Abdullah, 1996) Lebih lanjut, Rudolf Otto menemukan sesuatu yang mengagumkan dan benar-benar menarik serta menggetarkan hati dari pengalaman keberagamaan seseorang. Sementara itu, MirceaEliade menekankan adanya sesuatu yang dikultuskan "thesacred" yang tidak bisa dipisahkan dari seseorang yang memeluk agama. (Permata, 2000) Kemudian G. VanderLeeuw menegaskan bahwa sesorang yang beragama akan selalu bergantung kepada zat yang Maha Kuasa yang menguasai apapun yang ada di alam raya ini (thepower). Semua hal yang diutarakan tersebut adalah sesuatu yang fundamental yang pasti ada dari setiap pemeluk agama tanpa terkecuali. (Abdullah, 1996)

Setiap penelitian tentang agama pokok bahasannya pasti seputar fakta dan 
cara pengungkapannya. Temuan-temuan ini digali dari pengamatan atas realitas kebiasaan tata cara beragama dari seseorang, secara lebih rinci sikap maupun tindakan keagamaan seseorang sangat terlihat jelas pada saat mereka melakukan ritual-ritual agama, keyakinannya terhadap mitos-mitos maupun simbol-simbol agama, kepercayaan terhadap kitab suci dan sejauh mana ia menjadikan agama sebagai tuntunan dalam menjalankan aktivitas sehari-hari. (Dhavamony, 1995)

Hegel menambahkan bahwa pendekatan fenomenologi ini berhubungan dengan hal yang sedang digambarkan oleh seseorang dari apa yang dia pikir, kemudian nampak dalam realitas kesadaran serta dirasakan menjadi sebuah pengalaman dari seseorang tersebut. Lebih lanjut Husserlmenganggap bahwa fenomenologi ini menjadi suatu kajian studi yang berasaldari struktur kesadaran manusia dimana kesadaran tersebut mengarahkan pada objek di luar diri manusia tersebut. Tidak berhenti disitu, Husserl bahkan menemukan poin-poin penting yang menjadi tolak ukur dari metodologi fenomenologi agama itu sendiri, yaitu epochedan eideticvision. Makna dari epochedisini ialah "penundaan dari sebuah penilaian" yang bermaksud bahwa menghilangkan praduga yang muncul dan bisa berpengaruh pada pemahaman seseorang dari suatu hal tertentu. Sedangkan makna dari eideticvisionyaitu kemampuan dalam menerawang lebih jauh dari yang sebenarnya terjadi pada objek yang nampak.Penggunan baik epochemaupun eideticvisionini menjadi sebuah keharusan dari peneliti fenomenologi untuk mendapatkkan hasil penelitian yang benar-benar objektif. (Khoir, 2009)
Dari penjelasan diatas dapat disimpulkan bahwa, terdapat dua unsur fundamental yang harus ada dalam pendekatan fenomenologi yaitu apocheatau penangguhan anggapan awal dan eideticvisionyang berarti melihat lebih jauh dari apa yang terlihat. Dari dua cara inilah pengalaman keagamaan maupun fenomenafenomena dari suatu agama akan diketahui sampai pada struktur yang paling mendasar. (Khoir, 2009)

Terdapat istilah fenomenologi historis agama, yaitu penelitian secara sistematis yang mencoba mencari jawaban dari sejarah suatu agama. Penyelidikan ini ditugaskan untuk mengelompokkan atau mengklarifikasi beberapa data yang telah tersebar luas sehingga menjadi di satu pandangan yang utuh yang dapat diambil isi dan makna religius dari agama tertentu tersebut. Perilaku dan keyakinan keberagamaan seseorang kadangkala terlihat mirip antara agama satu dengan yang lain, sedangkan dalam tinjauan sejarah agama yang menjadi pembahasan adalah aspek kekhususan yang melekat dari agama tertentu. Sedangkan dalam kajian fenomenologi agama justru memperlihatkan perspektif yang sistematis dari gejala-gejala yang muncul dari suatu agama, hal ini bukan berarti bahwa fenomenologi mencoba untuk menyamaratakan ataupun memperbandingkan berbagai agama sebagai kesatuan-kesatuan yang besar tetapi justru akan menarik fakta dan gejala yang sama yang muncul dari agama yang berbeda-beda, kemudian dikumpulkan dan dipelajari secara berkelompok. Tujuan dari hal ini tidak lain adalah untuk memperoleh suatu perspektif yang sangat mendalam, detail dan terukur karena merupakan hasil dari pembahasan kelompok yang saling memperbandingkan antara satu data dengan data yang lain. (Dhavamony, 1995) 


\begin{abstract}
Dalam fenomenologi agama dimasukkan pula pendekatan insider(prioritas perspektif penganut agama) yang pada dasarnya membawa rasa
\end{abstract} empati yang besar sehingga dapat membawa seseorang merasa ikut mengerti dan mengalami dari apa yang sedang dirasakan oleh penganut agama lain. Sehingga akan menimbulkan pemahaman yang netral (menghilangkan pemikiran kurang percaya) dan membuang reaksi penilaian awal dari diri sendiri.Pendekatan semacam ini berusaha menghindari sejauh mungkin penilain-penilain teologis atau metafisis yang biasanya cenderung merusak atau mengaburkan usaha memahami apa yang harus ditemukan dan dinilai dalam istilah-istilahnya sendiri. (Cannon, 2002) Contohnya, haruskah seorang Muslim menafikan semua yang sah dan pantas bagi orang-orang Hindu hanya karena penganut Hindu tidak mengakui otoritas al-Qur'an dan terlihat lebih mementingkan pemujaan berhala? Dari sini tidak boleh ada pemahaman keliru dan harus menggunakan pendekatan empati yang ketat lewat fenomenologi agama. Atau peneliti dapat masuk ke dalam objek penelitian sehingga ia dapat mengatasi jarak sebagai subjek dengan penganut agama sebagai objek (insider-outsider). (Khoir, 2009)

Menurut NoengMuhadjir, secara ontologis pendekatan fenomenologi dalam penelitian agama mengakui empat kebenaran (sensual, logik, etik, transendental). (Khoir, 2009) Namun, hanya kebenaran transenden yang dibedakan menjadi dua yaitu kebenaranIlahiyah dan insaniyah. Kebenaran Ilahiyah didapat dari menafsirkan suatu teks serta mengembangkan maknanya tetapi tidak akan pernah bisa menjangkau kebenaran substansial dari ilahiyah tersebut, sedangkan kebenaran insaniyah merupakan hasil dari interaksi sesama manusia. Muhajir menambahkan, fenomenologi ini memiliki orientasi serta landasan pada nilainilai (valuebound) seperti nilai kemanusiaan, nilai keadilan dan lain sebagainya. (Muhadjir, 1989) Hal ini berbeda dengan positifisme yang selalu fokus pada objektivitas melalui metode natural science dan bebas nilai.

Berdasarkan pada hal-hal yang telah dijelaskan di atas, maka sudah jelas bahwa fenomenologi ini dilarang untuk menghasilkan suatu kontradiksi antara agama yang dianggap benar dengan yang tidak benar. Namun, dalam situasi terpaksa fenomenologi bisa membedakan antara agama yang dianggap murni dengan religius yang tidak murni, tetapi ini harus dilakukan dengan penuh kewaspadaan. (Ghazali, 2000) Maka dari itu, bidang kajian fenomenologi ini sebenarnya tidak sulit meliputi:

a. Menjelaskan dari apa yang sudah diketahui bersama cari sejarah agama, maka fenomenologi agama ini tidak akan pernah membedakan dirinya dengan agama manapun.

b. Fenomenologi bertugas untuk menyusun bagian fundamental agama ataupun sifat alamiah dari agama tertentu, dimana hal ini ini merupakan faktor yang menjadi asal usul penamaan dari semua agama.

c. Fenomenologi tidak akan pernah mempermasalahkan apakah gejala yang timbul dari suatu agama itu merupakan suatu kebenaran atau sesuatu yang memiliki nilai serta bagaimana hal tersebut bisa terjadi atau bahkan sampai menentukan besar kecilnya nilai dari keagamaan yang dianut oleh setiap manusia. Namun, apabila sampai mencoba untuk menentukan nilai 
keagamaan, maka nilai tersebut tidak pernah bersifat relatif tetapi selalu memiliki nilai absolut. Maka dari itu, titik tekan dari pembicaraan fenomenologi ialah Bagaimana fenomena tersebut nampak dan bagaimana cara ia menempatkan dirinya di hadapan kita.

Oleh karena itu, fenomenologi menegaskan bahwa setiap gejala yang tidak terikat tuntutan-tuntutan terhadap hal yang nyata maka dianggap tidak memiliki arti sama sekali. Meskipun begitu, fenomenologi agama di sini tidak akan menjelaskan suatu nilai (makna) serta kebenaran (fakta yang nampak) dari agama tertentu. (Ghazali, 2000) Selajutnya sudah jelas bahwa, fenomenologi agama memposisikan diri di antara dua kurung, menangguhkan serta menunda untuk menetapkan sesuatu (epoche).

3. Pendekatan Fenomenologis dalam Kajian Studi Islam

Jika diteliti lebih jauh, sebenarnya apa yang diungkapkan para fenomenolog tidaklah dirasa ganjil bagi kaum teologis mutakallimun dalam lingkungan agama Islam, Cuma didalam hal metodologinya dari keduanya terdapat perbedaan atau perbandingan yang sangat mencolok, bagi mutakallimun pemahaman beragama diperoleh dari wahyu (relevation), terlebih lagi golongan ini lebih menekankan pada pengertian wahyu yang tertulis, khususnya pada bangsa-bangsa yang mengenal budaya baca tulis (literarytradition). Para mutakallim tidak akan mencoba untuk menyentuh kepada aspek keberagamaan dalam wilayah kebudayaan yang nonliterasi.Mereka beranggapan justru budaya non-literasi inilah yang perlu untuk diagamakan. Di sisi lain, temuan dari para fenomenologis menjangkau jauh kebelakang ketika manusia belum mengenal baca tulis. Pendekatan fenomenolog bermula dari fenomena keberagamaan manusia yang apa adanya. Pendekatan ini tidak terbebani pada misi keagamaan tertentu yang menuntut untuk mencari dan memperbanyak jumlah pengikut. Para fenomenolog meneliti secara esensial, fundamental dan universal baik wilayahliterateataupun non-literate, baik masyarakat klasik maupun kontemporer. (Abdullah, 1996)

Namun tak dapat disangkal upaya sistimatisasi yang dilakukan fenomenologis memiliki validitas dan signifikansi yang tinggi karena inilah aspek pendekatan yang telah mengarahkan studi agama ke tingkat ilmiah. (Arifin, 2009) Meskipun beberapa tahun terakhir fenomenologis agama telah mencapai ketenaran, (Karim, 2004) namun hampir tidak ada upaya untuk menerapkan metode dan pandangan ini pada materi Islam, hal ini yang sama juga terjadi di eropa, tempat pendekatan fenomenologis berasal. Mengenai hal ini, nampaknya metode fenomenologis jauh lebih sesuai untuk menyelidiki komunitas agama yang menunjukkan diri mereka secara nonverbal, sehingga karena alasan inilah fenomenologis memberikan perhatian besarnya pada apa saja yang dianggap agama primitif. Padahal, dalam Islam sendiri telah menawarkan berbagai bidang pengembangan yang sangat banyak bagi siapa saja yang telah ahli dalam menggunakan pendekatan fenomenologi ataupun lainnya yang memang khusus digunakan dalam penelitian studi agama. (Arifin, 2009)

Semangat untuk mendalami agama Islam serta revolusi yang dilakukan dalam pengembangan metode fenomenologi ini setelah mendapat penghargaan dari semua pihak yang sedang mendalami tradisi tradisi keilmuan barat yang berkaitan langsung 
dengan tradisi dari agama Islam. Sebelum fenomenologi muncul, bisa dikatakan bahwa hampir sebagian besar tulisan yang dihasilkan oleh orientalis Barat yang menulis tentang agama Islam semuanya bersifat apatis bahkan dengan terbuka menunjukkan sikap yang kurang baik sampai kepada permusuhan terhadap persepsi-persepsi serta nilai dari agama Islam itu sendiri. Para orientalis Barat tidak hanya kurang memiliki kepekaan moral terhadap suatu komitmen penganut agama lain tetapi juga telah terbukti menggunakan metode keilmuan yang salah. Hingga diluruskan oleh fenomenologi yang menuntut bahwa setiap pengalaman yang muncul dari Islam harus dianggap sebagai objek studi yang memiliki nilai.

Kelompok yang mencurahkan waktu dan energinya untuk mempelajari Islam adalah pakar yang sangat memperhatikan agama, mereka memiliki tempat dalam tradisi studi agama dan berusaha menerapkan pendekatan ilmiah pada studi agama dengan tujuan dan metodenya sendiri dengan istilah fenomenologi. (Arifin, 2009) Ada dua aspek yang menandai pendekatan fenomenologis.

Aspek pertama dengan menyatakan bahwa fenomenologis adalah metode untuk memahami agama lain yang mencakup upaya pakar mengabaikan atau bersikap netral terhadap prefensi dan keyakinannya sendiri sebagai persiapan untuk mencoba merekonstruksi pengalaman penganut ajaran lain. Aspek yang terdapat dalam fenomenologi sangat diperlukan bagi studi Islam, aspek ini mempunyai peranan penting untuk meluruskankesalahan annemarie berbagai pendekatan yang tidak simpati dan cenderung bermusuhan yang telah berkembang dalam tradisi keilmuan orientalis Barat serta dapat membuka pintu baru dalam penetrasi pengalaman beragama
Islam dalam koridor yang lebih luas dan lebih penting lagi. Titik tertinggi cari capaian fenomenologis yang utama terletak dari pandangannya bahwa norma dari semua studi tentang agama adalah hasil pengalaman dari pengikutnya itu sendiri. Maka dari itu, sebenarnya apa yang telah dipraktekkan olehkajian seperti ini yaitu mengelaborasi makna yang terkandung dari ritual keagamaan yang telah dipraktekkan oleh pengikutnya. Lebih lanjut, kategorisasi untuk menyusun serta memahami pengalaman keberagamaan merupakan kategori yang benar-benar dibentuk oleh penganut suatu agama untuk pribadi dan dituangkan melalui tradisi maupun karya historis serta diceritakan melalui pengalaman-pengalamannya sendiri. (Arifin, 2009)

Aspek kedua dari pendekatan fenomenologi ini ialahmenyusun skema taksonomi untuk mengklarifikasikan gejala yang nampak antara batas komunitas agama dengankebudayaan.

Dengan mengumpulkan materi sebanyak mungkin fenomenologis berusaha dan yang akan mengelompokkan fenomena yang menunjukkan kesamaan sifat. Meskipun proses pengumpulan materi yang berkenaan dengan fenomena agama menuntut fenomenologis untuk menyelidiki karakter tertentu tradisi agama, maka tidak bisa memahami makna fenomena agamis jika tidak memfokuskan diri pada aspek historis, namun harus menelitinya dalam bidang yang lebih luas untuk mengetahui dorongan struktural, universal atau mendasar yang ditunjukkan fenomena tertentu. (Arifin, 2009) Langkah Operasional Fenomenologi Islam adalah sebagai berikut:

a. Mengklasifikasi fenomena-fenomena keagamaan dalam kategorisasi masingmasing seperti kategori tempat-tempat suci, waktu suci, tulisan-tulisan suci, 
kata-kata suci, mitos-mitos, festival, kurban dan lain-lain. Kegiatanini dilakukan dalam rangka untuk memahami esensi dari masing-masing fenomena tersebut.

b. Melaksanakan interpolasi ke dalam kehidupan pribadi dari peneliti, hal ini mengandung arti bahwa seorang peneliti diminta untuk berpartisipasi dan menyatu ke dalam sebuah keberagamaan dari objek penelitiannya guna mendapatkan pemahaman serta pengalaman untuk diri peneliti itu sendiri.

c. Menerapkan sikap epoche atau menunda untuk memberikan penilaian di awaldan selalu menggunakan sudut pandang yang netral.

d. Menemukan setiap hubungan struktural dari berbagai informasi yang telah dikumpulkan untuk mendapatkan pemahaman holistik dari berbagai aspek yang paling dalam dari suatu agama tertentu.

e. Menurut vanderLeeuw secara alami tahapan-tahapan ini akhirnya akan menghasilkan sebuah pemahaman yang otentik yang sesuai dengan realitas atau manifestasi dari Wahyu Tuhan.

f. Fenomenologi disini tidak berdiri sendiri tetapi selalu memiliki hubungan dengan pendekatan lain agar bisa menjaga sifat objektivitas. (Mudzhar, 2007)

Sedangkan dalam perspektif wahyu, realitas empiris merupakan manifestasi transendental yang nyata, maka dari itu yang mempunyai makna ialah sesuatu yang ada hubungannya dengan unsur transendental. Dipertegas dalam Al-Qur'an bahwa banyak ditemukan ayat yang nenjelaskan hubungan antara unsur empiris dengan transendental. Lebih dari itu, dijelaskan bahwa fakta empiris tidak akan memberikan makna sama sekali jika dipisah dari unsur totalitasnya, hal seperti itu yang ingin ditunjukkan oleh Barat yang ingin melewati batas-batas realita empiris.

Oleh karena itu, wahyu harus dilihat menjadi sebuah fenomena yang tersusun dari tanda-tanda, bukan sebatas pernyataan-pernyataan yang diakses langsung. Kemudian untuk memahami wahyu tersebut diperlukan interpretasi yang konsisten dan konstan. Bahkan, ditegaskan juga dalam Al-Qur'an dimana untuk memahaminya perlu melewati proses penalaran, pemikiran dan kontemplasi. (Safi, 2001)

Fenomenologi dalam studi Islam mengungkapkan makna dari suatu gejala sehingga gejala tersebut dapat dipahami dan dapat diterapkan dalam ajaran-ajaran normatif, kegiatan-kegiatan keagamaan, institusi-institusi keagamaan, tradisi-tradisi dan simbol-simbol keagamaan. (Suparlan, 2001) Dengan demikian, pendekatan fenomenologi dapat dipakai untuk meneliti fenomena ritual agama, seperti sholat, zakat, puasa dan haji dalam realitas sosial. (Abdullah, 1996)

Fakta yang memprihatinkan yaitu studi keislaman sebagai sebuah agama sangat tidak berkembang dan kurang mendapat perhatian di berbagai Unversitasuniversitas Islam. Sedikit sekali Fakultas yang menyediakan tempat untuk memberi peluang bagi mahasiswa-mahasiswanya agar bisa mendalami dan mengembangkan tradisi Islam dan menawarkan program selain program pengantar Islam. Oleh karena itu, pemahaman terhadap Islam sebenarnya bergantung dalam dua hal, yaitu:

a. Mengakui Islam sebagai bagian utama dari segmen aktivitas keagamaan seseorang. 
b. Mengakui bahwa terdapat disiplin ilmu yang unggul tentang studi keislaman. Terutama mau memakai metode dan segala sumber daya yang otentik dari agama Islam sendiri. (Arifin, 2009)

Selanjutnya, tugas dari seorang fenomenolog yaitu memperlihatkan bahwa Islam perlu dikaji secara sungguh-sungguh sehingga mampu memberi kontribusi terhadap cara pandang seseorang tentang humanitas yang baik. sebagai mahasiswa agama, hendaknya menyadari kenyataan bahwa konsep agama merupakan bagian dari diri kita sehingga sampai kepada suatu pandangan tentang agama pada umumnya dengan pengalaman yang diperoleh dari hidupnya. (Connoly, 2002)

Namun, pendekatan fenomenologis juga bukan tanpa kekurangan. pendekatan fenomenologis tampaknya terlalu menekankan hal-hal yang bersifat steril sekaligus abstrak yang akhirnya kurang memiliki kerangka berpikir etis pragmatis, maka dari itu perlu diberi ajaran-ajaran doktrinal teologi kongkret dan mengikat. Sebab, pendekatan dalam fenomenologi hanya bisa didapat lewat cara-cara kongkret melalui ajaran agama. Seperti halnya sebuah sinar, ia baru bjsa dinikmati jika sudah berhasil dimanifestasikan menjadi suatu warna-warna tertentu. (Abdullah, 1996)

Oleh karena hal tersebut, Charles J. Adams menawarkan sebuah rekomendasi berupa enam wilayah kajian dalam memahami studi Islam termasuk dengan menggunakan fenomenologi. (Abdullah, 1996) Rekomendasi tersebut berupa:

a. Studi tentang Al-Qur'an, khususnya dalam gagasan, ajaran serta bagaimana pandangan dunia umum tentang AlQur'an.

b. Sejarah tentang teologi Islam di masamasa permulaan Islam. c. Kajian sufistik dengan menekankan pada hasil karya individual muslim, kajian teks serta tarikat-tarikatnya.

d. Studi tentang aliran Islam yang berfokus pada keunikan dan kontribusinya dalam agama Islam.

e. Kajian agama yang dipraktikkan oleh masyarakat Islam.

f. Studi yang berkaitan tentang sejarah dari agama yang lahir di Eropa dan Amerika dengan memakai pendekatanpendekatan ilmiah.

g. Signifikansi dan Kontribusi Pendekatan Fenomenologis dalam Studi Islam

Kuntowijoyo mengatakan bahwa manusia membutuhkan ilmu sosial profetik, ialah sebuah ilmu sosial yang tidak sekedar mendeskripsikan serta mengubah suatu fenomena, melainkan juga bisa memberikan petunjuk arah kemana transformasi harus dijalankan, oleh siapa dan bertujuan apa. (Nata, 2001) Ilmu sosial ini harus bisa merubah gejala yang tampak sesuai dengan cita-cita etik profetik tertentu. Perubahannya juga harus mengacu pada tiga hal utama yaitu, liberasi, transendensi serta cita-cita kemanusiaan.

Untuk memperoleh hal tersebut, kita tidak bisa menggunakan pendekatan fenomenologi semata, tetapi juga dengan berbagai disiplin keilmuan lainnya, misalnya menggunakan ilmu antrologi dan lain-lain. Sehingga, lewat pendekatan antropologi fenomenologi ini maka akan diidapati hubungan dari suatu agama dengan negara.

\section{PENUTUP}

Pendekatan fenomenologi ialah sebuah pendekatan ilmiah yang berupaya mencari esensi atau hakikat dari apa yang sebenarnya terjadi dibalik segala macam bentuk manifestasi agama yang terjadi dalam kehidupan manusia. Pendekatan 
fenomenologi disini tidak menawarkan cara berpikir yang eksklusif sebagaimana aliranaliran filsafat yang ada sebelumnya yang kesemuanya menghasilkan isme-isme besar tetapi dengan suatu metode saja dalam menyelesaikan permasalahan.

Orientasi utama dari kajian fenomenologi agama yaitu aspek pengalaman dari keberagamaan seseorang, kemudian dengan konsisten berupaya menggambarkan atau mendeskripsikan yang berfokus pada keimanan atau kepercayaan objek penelitian. Pendekatan ini meninjau agama sebagai suatu komponen yang unik dan berbeda kemudian dikaji dengan hati-hati sesuai tradisi keagamaan seseorang untuk menemukan sebuah pemahaman di dalamnya. Fenomenologi agama lahir sebagai usaha untuk menghindari penggunaan pendekatan-pendekatan sempit, normatif dan etnosentris dengan berusaha menggambarkan pengalaman-pengalaman agama seakurat mungkin.

Pendekatan fenomenologi dalam studi Islam mengungkapkan makna dari suatu gejala sehingga gejala tersebut dapat dipahami dan dapat diterapkan dalam ajaran-ajaran normatif, kegiatan-kegiatan keagamaan, institusi-institusi keagamaan, tradisi-tradisi dan simbol-simbol keagamaan.

\section{REFERENSI}

Abdullah, Amin. (1996). Studi Agama Normativitas atau Historisitas. Yogyakarta: Pustaka Pelajar.

Abdullah, Taufik kata pengantar dalam Taufik Abdullah \& M. Rusli Karim (ed.). (2004) .Metodologi Penelitian Agama; Suatu Pengantar. Yogyakarta: Tiara Wacana.
Cannon, Dale. (2002). Enam Cara Beragama. Jakarta:Depag RI dan CIDA.

Connoly, Peter. (2002). Aneka Pendekatan Studi Agama. Yogyakarta:LKIS Yogyakarta.

Dhavamony, Mariasusai.

Fenomenologi

Agama.

Yogyakarta:KANISIUS.

Hadiwijoyo, Harun. (1992). Sari Sejarah

Filsafat Barat 2. Yogyakarta: Kanisius.

Joachim Wach, (2000). "Perkembangan dan Metode Studi Agama", dalam Ahmad Norma Permata (Ed. dan pent), Metodelogi Studi Agama, Cet. 1. Yogyakarta: Pustaka Pelajar.

Khoir, Tholhatul. (2009). Islam Dalam Berbagai Pembacaan Kontemporer. Yogyakarta:Pustaka Pelajar.

Mudzhar, Atho. (2007). Pendekatan Studi Islam dalam Teori dan Praktek. Yogyakarta: Pustaka Pelajar.

Muhadjir, Noeng. (1989). Metodologi Penelitian Kualitatif . Yogyakarta: Rake Sarasin,.

Muhadjir, Noeng. (1998). Filsafat Ilmu:

Telaah Sistematis Fungsional

Komparatif, Cet. II. Yogyakarta: Rake Sarasin.

Nata, Abuddin. (2001). Metodologi Islam. Jakarta: Raja Grafindo Persada.

Safi, Lousy. (2001). Sebuah Refleksi Perbandingan Metode Penelitian Islam dan Barat Ancangan Metodologi Alternatif, Terj. Imam Khoiri. Jakarta: PT Tiara Wacana Yoga.

Suparlan, Parsudi. (2001). Penelitian Agama Islam. Bandung: Nuansa.

Syamsul Arifin, (2009). Studi Agama Perspektif Sosiologis dan Isu-isu Kontenporer. Malang:UMM Press. 